Article

\title{
Three Novel Xanthones from Garcinia paucinervis and Their Anti-TMV Activity
}

Yu-Ping Wu ${ }^{1}$, Wei Zhao ${ }^{2}$, Zhen-Yuan Xia ${ }^{1}$, Guang-Hui Kong ${ }^{1}$, Xiu-Ping Lu ${ }^{1, *}$, Qiu-Fen $\mathrm{Hu}^{1,3}$ and Xue-Mei Gao ${ }^{3, *}$

1 Yunnan Academy of Tobacco Agricultural Sciences, Yuxi 653100, China; E-Mails: ypwumm@163.com (Y.-P.W.); zyxia@yntsti.com (Z.-Y.X.); 13908776036@163.com (G.-H.K.); xplu1970@163.com (X.-P.L.); huqiufena@aliyun.com (Q.-F.H.)

2 Key Laboratory of Tobacco Chemistry of Yunnan Province, Yunnan Academy of Tobacco Science, Kunming 650106, China; E-Mail: zhaoweizhaorong@126.com

3 Key Laboratory of Chemistry in Ethnic Medicinal Resources, State Ethnic Affairs Commission and Ministry of Education, Yunnan University of Nationalities, Kunming 650031, China

* Authors to whom correspondence should be addressed;

E-Mails: gao_xuemei@hotmail.com (X.-M.G.); xplu1970@163.com (X.-P.L.);

Tel./Fax: +86-871-591-0017 (X.-M.G.).

Received: 6 June 2013; in revised form: 2 August 2013 / Accepted: 5 August 2013 /

Published: 13 August 2013

\begin{abstract}
Phytochemical investigations of the leaves of Garcinia paucinervis resulted in the isolation of three new xanthones 1-3 and five known analogues 4-8. Structural elucidations of 1-3 were performed by spectral methods such as 1D and 2D (HMQC, HMBC, and ROESY) NMR spectroscopy, in addition to high resolution mass spectrometry. Compounds 1-3 showed anti-TMV activities, with inhibition rates above $20 \%$, especially for 1 , which had a lower $\mathrm{IC}_{50}$ value of $21.4 \mu \mathrm{M}$.
\end{abstract}

Keywords: Garcinia paucinervis; xanthones; anti-tobacco mosaic virus

\section{Introduction}

The genus Garcinia (Guttiferae family) is known to be a rich source of polyisoprenylated benzophenones and xanthones, some of which have shown various biological activities such as antibacterial [1], antifungal [2], anti-inflammatory [3], antioxidant [4], apoptosis-inducing [5,6], and 
cytotoxic effects [7]. Garcinia paucinervis is a valuable species distributed in the Yunnan and Guangxi provinces of China [8]. The present studies on chemical constituents of the acetone extract of the dried leaves of G. paucinervis afforded three new xanthones 1-3 (Figure 1), and five known analogues, namely nigrolineaxanthone K (4) [9], 5-O-methylxanthone V1 (5) [10], ananixanthone (6) [11], cudraxanthone $G$ (7) [12], and merguenone (8) [13] (Figure 1). In this paper, we describe the isolation, structure elucidation, and anti-tobacco mosaic virus (anti-TMV) activities of these compounds.

Figure 1. The structures of compounds 1-8.
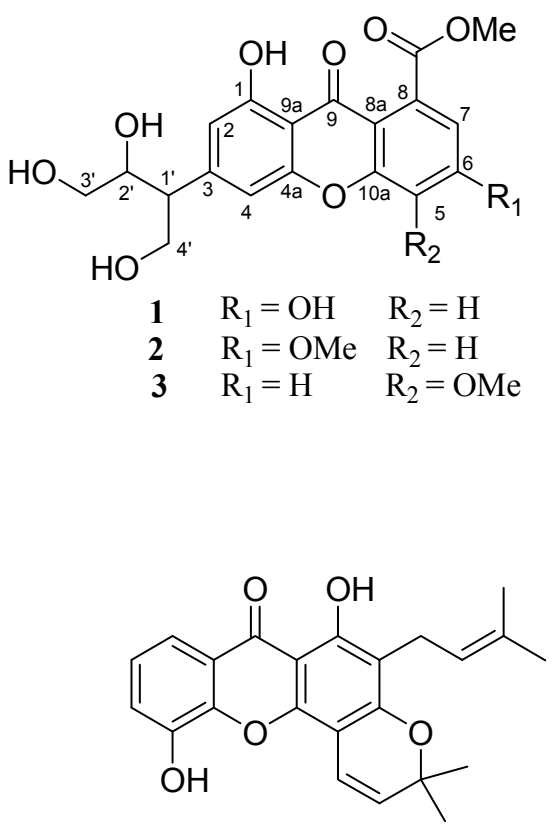

ananixanthone

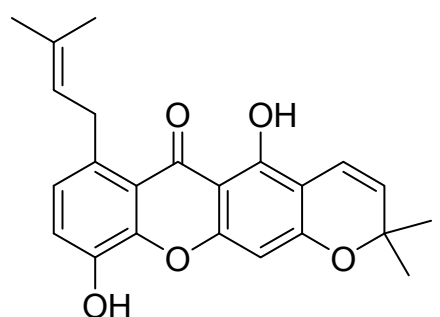

nigrolineaxanthone $\mathrm{K}$

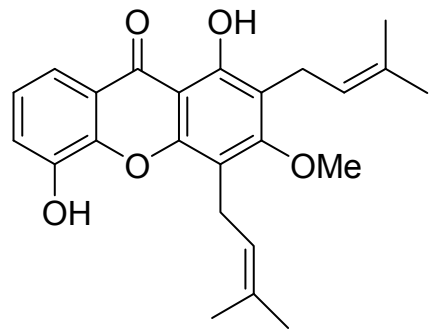

cudraxanthone $\mathrm{G}$

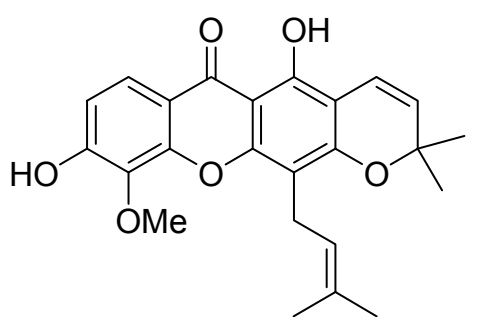

5-O-methylxanthone V1

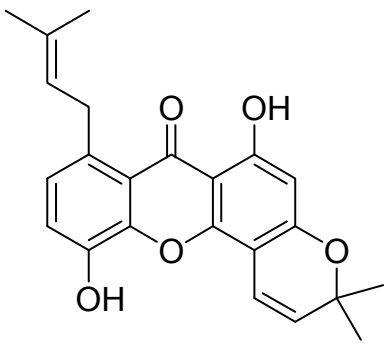

merguenone

\section{Results and Discussion}

Compound 1 was obtained as a yellow amorphous powder. Its molecular formula was determined to be $\mathrm{C}_{19} \mathrm{H}_{18} \mathrm{O}_{9}$ on the basis of positive HR-ESI-MS (calcd. for [M+Na] ${ }^{+} \mathrm{m} / z$ 413.0842; found, 413.0849) with 11 degrees of unsaturation. The UV absorptions at 310, 246, and $210 \mathrm{~nm}$ showed an extended chromophore and a substituted benzene ring, suggesting a xanthone skeleton. Its IR spectral data showed the presence of hydroxy groups $\left(3,415 \mathrm{~cm}^{-1}\right)$ and phenyl groups $(1,658,1,584$ and $\left.1,548 \mathrm{~cm}^{-1}\right)$. The ${ }^{1} \mathrm{H}-\mathrm{NMR}$ spectrum (Table 1) displayed four aromatic methines $\left[\delta_{H} 6.75(1 \mathrm{H}, \mathrm{s}, \mathrm{H}-2)\right.$, $7.00(1 \mathrm{H}, \mathrm{s}, \mathrm{H}-4), 6.89(1 \mathrm{H}, \mathrm{s}, \mathrm{H}-5), 6.80(1 \mathrm{H}, \mathrm{s}, \mathrm{H}-7)]$, one methoxy group $\left(\delta_{H} 4.04\right)$, two oxygenated methylenes $\left[\delta_{H} 4.63\left(2 \mathrm{H}, \mathrm{m}, \mathrm{H}-3^{\prime}\right)\right.$ and 4.13 and $\left.4.19\left(2 \mathrm{H}, \mathrm{m}, \mathrm{H}-4^{\prime}\right)\right]$, and two methines, including one oxygenated $\delta_{H} 5.14\left(1 \mathrm{H}, \mathrm{m}, \mathrm{H}-2^{\prime}\right)$ and one non-oxygenated $\left[\delta_{H} 4.41\left(1 \mathrm{H}, \mathrm{m}, \mathrm{H}-1^{\prime}\right)\right]$ one, and two hydroxy protons $\left[\delta_{H} 13.07(1 \mathrm{H}, \mathrm{s}, \mathrm{HO}-1), \delta_{H} 12.83(1 \mathrm{H}, \mathrm{s}, \mathrm{HO}-6)\right]$. Further analysis of its ${ }^{13} \mathrm{C}-\mathrm{NMR}$ (DEPT) data (Table 1) revealed the presence of one ketone and one ester carbonyls, twelve aromatic carbons (four of which were protonated) indicative of two substituted phenyl rings, one methoxy group, two methylenes, and two methines. By careful analysis of the above data, we concluded that $\mathbf{1}$ was a xanthone analogue. One spin coupling system from C-1' to C-4' was deduced from correlations between $\mathrm{H}-4^{\prime} / \mathrm{H}-1^{\prime} / \mathrm{H}-2^{\prime} / \mathrm{H}-3^{\prime}$ observed in the ${ }^{1} \mathrm{H},{ }^{1} \mathrm{H}-\mathrm{COSY}$ spectrum, and the $-\mathrm{H}\left(\mathrm{CH}_{2} \mathrm{OH}\right) \mathrm{CHOHCH}{ }_{2} \mathrm{OH}$ group was connected at $\mathrm{C}-3$ according to the HMBC correlations from $\mathrm{H}-1$ ' to $\mathrm{C}-2, \mathrm{C}-3$, and $\mathrm{C}-4$. This 
fragment is very rare in xanthones, and it should be a degradation product of an isopentene group. The two hydroxy groups were located at C-1 and C-6 positions, as deduced from the HMBC correlations (Figure 2) of H-2 with C-1, and of H-5 and H-7 with C-6. HMBC correlations from OMe $\left(\delta_{H} 4.04,3 \mathrm{H}, \mathrm{s}\right)$ and H-7 $\left(\delta_{H} 6.80,1 \mathrm{H}, \mathrm{s}\right)$ to a carbonyl $\left(\delta_{C} 169.4, \mathrm{~s}\right)$ suggested that the methyl ester was connected at C-8. From above information, the gross structure of $\mathbf{1}$ was established as paucinervin E (Figure 1).

Table 1. ${ }^{1} \mathrm{H}-(500 \mathrm{MHz})$ and ${ }^{13} \mathrm{C}-\mathrm{NMR}(125 \mathrm{MHz})$ data for $\mathbf{1 - 3}$ ( $\delta$ in ppm and $J$ in $\mathrm{Hz}$, data recorded in $\left.\mathrm{C}_{5} \mathrm{D}_{5} \mathrm{~N}\right)$.

\begin{tabular}{|c|c|c|c|c|c|c|}
\hline \multirow{2}{*}{ No. } & \multicolumn{2}{|r|}{1} & \multicolumn{2}{|r|}{2} & \multicolumn{2}{|r|}{3} \\
\hline & $\delta_{\mathrm{C}}(\mathbf{m})$ & $\delta_{\mathrm{H}}(\mathrm{m}, J, \mathrm{~Hz})$ & $\delta_{\mathrm{C}}(\mathrm{m})$ & $\delta_{\mathrm{H}}(\mathrm{m}, J, \mathrm{~Hz})$ & $\delta_{\mathrm{C}}(\mathrm{m})$ & $\delta_{\mathrm{H}}(\mathrm{m}, J, \mathrm{~Hz})$ \\
\hline 1 & $162.7 \mathrm{~s}$ & & $161.8 \mathrm{~s}$ & & $161.4 \mathrm{~s}$ & \\
\hline 2 & $108.5 \mathrm{~d}$ & $6.75 \mathrm{~s}$ & $108.8 \mathrm{~d}$ & $6.75 \mathrm{~s}$ & $110.0 \mathrm{~d}$ & $6.94 \mathrm{~d}(1.8)$ \\
\hline 3 & $149.1 \mathrm{~s}$ & & $149.0 \mathrm{~s}$ & & $145.2 \mathrm{~s}$ & \\
\hline 4 & $104.1 \mathrm{~d}$ & $7.00 \mathrm{~s}$ & $104.8 \mathrm{~d}$ & $7.00 \mathrm{~s}$ & $108.8 \mathrm{~d}$ & $7.07 \mathrm{~d}(1.8)$ \\
\hline 5 & $103.0 \mathrm{~d}$ & $6.89 \mathrm{~s}$ & $102.3 \mathrm{~d}$ & $6.93 \mathrm{~s}$ & $156.0 \mathrm{~s}$ & \\
\hline 6 & $165.1 \mathrm{~s}$ & & $167.1 \mathrm{~s}$ & & $121.5 \mathrm{~d}$ & $7.70 \mathrm{~d}(8.8)$ \\
\hline 7 & $113.8 \mathrm{~d}$ & $6.80 \mathrm{~s}$ & $112.7 \mathrm{~d}$ & $6.84 \mathrm{~s}$ & $125.2 \mathrm{~d}$ & $7.39 \mathrm{~d}(8.8)$ \\
\hline 8 & $136.8 \mathrm{~s}$ & & $137.1 \mathrm{~s}$ & & $126.5 \mathrm{~s}$ & \\
\hline 9 & $181.9 \mathrm{~s}$ & & $181.8 \mathrm{~s}$ & & $181.5 \mathrm{~s}$ & \\
\hline $4 a$ & $155.6 \mathrm{~s}$ & & $155.0 \mathrm{~s}$ & & $157.0 \mathrm{~s}$ & \\
\hline $8 a$ & $109.2 \mathrm{~s}$ & & $109.7 \mathrm{~s}$ & & $119.4 \mathrm{~s}$ & \\
\hline $9 a$ & $107.4 \mathrm{~s}$ & & $107.7 \mathrm{~s}$ & & $107.8 \mathrm{~s}$ & \\
\hline $10 \mathrm{a}$ & $158.4 \mathrm{~s}$ & & $157.2 \mathrm{~s}$ & & $146.8 \mathrm{~s}$ & \\
\hline $1^{\prime}$ & $42.1 \mathrm{~d}$ & $4.41 \mathrm{~m}$ & $43.0 \mathrm{~d}$ & $4.44 \mathrm{~m}$ & $41.8 \mathrm{~d}$ & $4.42 \mathrm{~m}$ \\
\hline $2^{\prime}$ & $72.3 \mathrm{~d}$ & $5.14 \mathrm{~m}$ & $72.0 \mathrm{~d}$ & $5.29 \mathrm{~m}$ & $72.0 \mathrm{~d}$ & $5.13 \mathrm{~m}$ \\
\hline $3^{\prime}$ & $66.0 \mathrm{t}$ & $4.63 \mathrm{~m}$ & $66.0 \mathrm{t}$ & $4.74 \mathrm{~m}$ & $66.2 \mathrm{t}$ & $4.64,4.71 \mathrm{~m}$ \\
\hline $4^{\prime}$ & $61.8 \mathrm{t}$ & $4.13,4.19 \mathrm{~m}$ & $62.0 \mathrm{t}$ & $4.20 \mathrm{~m}$ & $61.8 \mathrm{t}$ & $4.17,4.22 \mathrm{~m}$ \\
\hline $5^{\prime}$ & $169.4 \mathrm{~s}$ & & $169.7 \mathrm{~s}$ & & $169.0 \mathrm{~s}$ & \\
\hline $5-\mathrm{OMe}$ & & & & & $55.9 \mathrm{q}$ & $3.79 \mathrm{~s}$ \\
\hline 6-OMe & & & $56.2 \mathrm{q}$ & $3.80 \mathrm{~s}$ & & \\
\hline $5^{\prime}-\mathrm{OMe}$ & $52.4 \mathrm{q}$ & $4.04 \mathrm{~s}$ & $52.5 \mathrm{q}$ & $4.11 \mathrm{~s}$ & $52.5 \mathrm{q}$ & $4.02 \mathrm{~s}$ \\
\hline Ar-OH-1 & & $13.07 \mathrm{~s}$ & & $13.79 \mathrm{~s}$ & & $13.22 \mathrm{~s}$ \\
\hline Ar-OH-6 & & $12.83 \mathrm{~s}$ & & & & \\
\hline
\end{tabular}

Figure 2. The key HMBC and COSY correlations of compound 1.

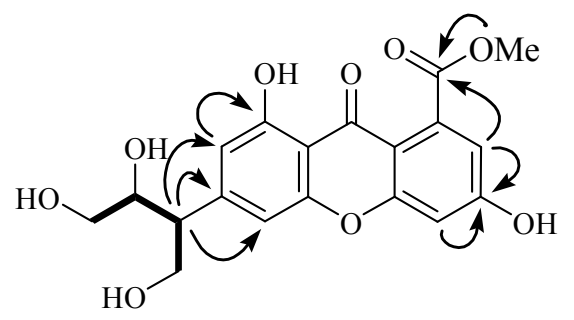

Compound 2, a yellow amorphous powder, was assigned the molecular formula $\mathrm{C}_{20} \mathrm{H}_{20} \mathrm{O}_{9}$, based on the HR-ESI-MS which revealed the $[M+\mathrm{Na}]^{+}$peak at $\mathrm{m} / z 427.1101$ (calcd. for $\mathrm{C}_{20} \mathrm{H}_{20} \mathrm{NaO}_{9}{ }^{+}$. 427.1005). Its UV and IR absorption bands were very similar to those of 1 . Analysis of the ${ }^{13} \mathrm{C}-\mathrm{NMR}$, 
DEPT, and HSQC spectra revealed that 2 also contained one ketone and one ester carbonyls, twelve aromatic carbons (four of which were protonated) indicative of two substituted phenyl rings, two methoxy groups, two methylenes, and two methines. By careful comparison, we found that the ${ }^{13} \mathrm{C}$-NMR spectral data of $\mathbf{2}$ were almost identical to those of $\mathbf{1}$, expect for the presence of one more methoxy group in 2. The key HMBC correlation of $\mathrm{H}-(\mathrm{MeO})\left(\delta_{H} 3.80,3 \mathrm{H}\right.$, s) with $\mathrm{C}-6\left(\delta_{C} 167.1, \mathrm{~s}\right)$ indicated a methoxy group at C-6 in 2, instead of a hydroxy group at C-6 in 1. Finally, compound 2 was identified as paucinervin $\mathrm{F}$ (Figure 1).

Compound 3, obtained as a yellow amorphous powder, gave the molecular formula $\mathrm{C}_{20} \mathrm{H}_{20} \mathrm{O}_{9}$, as revealed by its HR-ESI-MS at $m / z 427.1001[M+\mathrm{Na}]^{+}$(calcd. for $\mathrm{C}_{20} \mathrm{H}_{20} \mathrm{NaO}_{9}{ }^{+}$. 427.1005). Its UV, IR, ${ }^{1} \mathrm{H}$, and ${ }^{13} \mathrm{C}$ were very similar to 2 : one ketone and one ester carbonyls, twelve aromatic carbons (four of which were protonated) indicative of two substituted phenyl rings, two methoxy groups, two methylenes, and two methines. The only difference between $\mathbf{3}$ and $\mathbf{2}$ is that the methoxy group was at C-5 in 3 instead of at C-6 in 2, which was futher confirmed by the key HMBC correlation of $\mathrm{H}-(\mathrm{MeO})$ $\left(\delta_{H} 3.79,3 \mathrm{H}, \mathrm{s}\right)$ with $\mathrm{C}-6\left(\delta_{C} 156.0, \mathrm{~s}\right)$. Thus, compound 3 was finally identified as paucinervin $\mathrm{G}$ (Figure 1).

Since the $\mathrm{C}-\mathrm{C}$ bonds can rotate randomly, it is very difficult to determine the relative configurations of $\mathrm{C}-1$ ' and $\mathrm{C}-2$ ' through only spectroscopic analysis. We tried to determine the relative configuration of 1 by $\mathrm{CD}$ spectra and X-ray crystallography, but unfortunately, we failed to obtain the desired results, and the relative configurations of $\mathrm{C}-\mathbf{1}^{\prime}$ and $\mathrm{C}-2^{\prime}$ in compounds $\mathbf{1}-\mathbf{3}$ thus remain unassigned.

By comparison with NMR data in literatures, five known analogues, namely nigrolineaxanthone $\mathrm{K}$ (4) [9], 5-O-methylxanthone V1 (5) [10], ananixanthone (6) [11], cudraxanthone G (7) [12], and merguenone (8) [13], were identified.

Compounds 1-8 were tested for their anti-TMV activity using the half-leaf method [14,15]. Ningnanmycin, a commercial biochemical pesticide used against virus diseases on tomato, pepper, melons, tobacco, and many other crops with high efficiency, was used as a positive control. The antiviral inhibition rates of compounds 1-8 at the concentration of $20 \mu \mathrm{M}$ are listed in Table 2 . Compounds 1-3 showed anti-TMV activities with inhibition rate above $20 \%$. Compound $\mathbf{1}$ is more active with lower $\mathrm{IC}_{50}$ value of $21.4 \mu \mathrm{M}$ perhaps because of the presence of hydroxy groups. The interactions through hydrogen bonding with other moieties would be the main factor.

Table 2. Anti-TMV Activity of 1-7 on Garcinia paucinervis Leaf ${ }^{\text {a }}$.

\begin{tabular}{ccc}
\hline No. & \% Inhibition at $\mathbf{2 0} \boldsymbol{\mu M}$ & $\mathbf{I C}_{\mathbf{5 0}}(\boldsymbol{\mu M})$ \\
\hline 1 & $43.2 \pm 2.3$ & $21.4 \pm 2.3$ \\
2 & $28.7 \pm 3.0$ & $42.8 \pm 3.0$ \\
3 & $24.8 \pm 2.2$ & $53.6 \pm 2.2$ \\
4 & $9.22 \pm 2.8$ & $\geq 200$ \\
5 & $18.9 \pm 2.6$ & $82.4 \pm 2.6$ \\
6 & $17.8 \pm 2.3$ & $68.9 \pm 2.3$ \\
7 & $16.1 \pm 3.0$ & $52.8 \pm 3.0$ \\
8 & $13.1 \pm 3.0$ & $\geq 200$ \\
Ningnamycin & $30.5 \pm 2.4$ & $36.9 \pm 2.4$ \\
\hline
\end{tabular}

${ }^{\mathrm{a}}$ All results are expressed as mean $\pm \mathrm{SD} ; n=3$. 


\section{Experimental}

\subsection{General}

Ultraviolet absorption spectra were recorded using a Perkin-Elmer Lambda L14 spectrometer. A Perkin Elmer Spectrum 100 FT-IR spectrometer was used for scanning IR spectroscopy with $\mathrm{KBr}$ pellets. The ${ }^{1} \mathrm{D}$ and ${ }^{2} \mathrm{D}$ NMR spectra were recorded on a Bruker AV-400 spectrometer with TMS as the internal standard. Chemical shifts $(\delta)$ were expressed in ppm with reference to the solvent signals. HRMS were obtained using a nanoLC-MS/MS system, with a nanoAcquity ultra-performance liquid chromatography (UPLC) module and a quadrupole time-of-flight (Q-TOF) spectrometer equipped with a nanoelectrospray ion source (Waters, Milford, MA, USA) and connected to a lock-mass apparatus to perform a real-time calibration correction. Column chromatography was performed with silica gel (200-300 mesh, Qingdao Marine Chemical, Inc., Qingdao, China), Sephadex LH-20 (Pharmacia, Sweden), and reversed-phase $\mathrm{C}_{18}$ silica gel (250 meshes, Merck, Germany). Precoated TLC sheets of silica gel $60 \mathrm{GF}_{254}$ were used. An Agilent 1100 series equipped with an Alltima $\mathrm{C}_{18}$ column $(4.6 \times 250 \mathrm{~mm})$ was used for HPLC analysis, and semipreparative and preparative Alltima C18 columns or Zorbax SB-C18 columns $(9.4 \times 250 \mathrm{~mm}$ and $22 \times 250 \mathrm{~mm})$ were used in sample preparation. Spots were visualized by heating silica gel plates sprayed with $10 \% \mathrm{H}_{2} \mathrm{SO}_{4}$ in EtOH.

\subsection{Plant Material}

The leaves of Garcinia paucinervis were collected in October 2010 from the district of XiShuangBanNa Prefecture, Yunnan Province, China. The plant was identified by Pan-Yu Ren. A voucher specimen has been deposited at the Key Laboratory of Ethnic Medicine Resource Chemistry (Yunnan University of Nationalities), State Ethnic Affairs Commission \& Ministry of Education.

\subsection{Extraction and Isolation}

An acetone extract prepared from the leaves of Garcinia paucinervis $(5.5 \mathrm{~kg}$ ) was decolorized by MCI GEL(polystyrene polymer based packing material) and chromatographed on a silica gel column eluting with hexane/acetone $(1: 0,4: 1,2: 1,1: 1$, and $0: 1)$ to afford five fractions A-E. Further separation of fraction B (42 g) on silica gel, eluted with petroleum ether-acetone (9:1-1:2), yielded fractions B1-B7. Fraction B2 (6.28 g) was subjected to silica gel column chromatography using petroleum ether-acetone followed by semipreparative $\mathrm{HPLC}\left(78 \% \mathrm{MeOH}-\mathrm{H}_{2} \mathrm{O}\right.$, flow rate $12 \mathrm{~mL} / \mathrm{min}$ ) to give 3 (1.8 mg), 5 (42.7 mg), and 7 (33.3 mg). Fraction B3 (5.72 g), upon separation on silica gel using petroleum ether-acetone and semipreparative $\mathrm{HPLC}\left(70 \% \mathrm{MeOH}-\mathrm{H}_{2} \mathrm{O}\right.$, flow rate $\left.12 \mathrm{~mL} / \mathrm{min}\right)$, afforded 1 (1.6 mg), 4 (11.8 mg), 6 (14.6 mg). Fraction B4 (11.6 g) was subjected to silica gel column chromatography using petroleum ether-acetone and semipreparative $\mathrm{HPLC}\left(65 \% \mathrm{MeOH}-\mathrm{H}_{2} \mathrm{O}\right.$, flow rate $12 \mathrm{~mL} / \mathrm{min})$ to yield $\mathbf{2}(1.2 \mathrm{mg}), \mathbf{8}(3.6 \mathrm{mg})$.

Paucinervin E (1): Yellow amorphous powder, UV (MeOH) $\lambda_{\max }(\log \varepsilon): 210$ (4.30), 246 (3.62), 310 (3.94) nm; IR (KBr) $v_{\max }: 3,415,3,076,2,923,2,865,1,725,1,658,1,584,1,548,1,460,1,372,1,128$, 1,076, 878, $729 \mathrm{~cm}^{-1} ;{ }^{1} \mathrm{H}$ - and ${ }^{13} \mathrm{C}-\mathrm{NMR}$ : see Table 1; ESIMS $\mathrm{m} / z$ (positive ion mode) $413[\mathrm{M}+\mathrm{Na}]^{+}$; HRESIMS (positive ion mode) $\mathrm{m} / z 413.0842[\mathrm{M}+\mathrm{Na}]^{+}$(calcd. $\mathrm{C}_{19} \mathrm{H}_{18} \mathrm{NaO}_{9}$ for 413.0849). 
Paucinervin F (2): Yellow amorphous powder, UV (MeOH) $\lambda_{\max }(\log \varepsilon) 210$ (4.38), 248 (3.57), 312 (4.01) nm; IR (KBr) $v_{\max } 3,418,3,080,2,919,2,872,1,729,1,655,1,593,1,543,1,462,1,375,1,125$, 1,074, 882, $725 \mathrm{~cm}^{-1}$; ESIMS $\mathrm{m} / z$ (positive ion mode) $427[\mathrm{M}+\mathrm{Na}]^{+}$; HRESIMS (positive ion mode) $m / z 427.1011[\mathrm{M}+\mathrm{Na}]^{+}$(calcd. $\mathrm{C}_{20} \mathrm{H}_{20} \mathrm{NaO}_{9}$ for 427.1005).

Paucinervin G (3): Yellow amorphous powder, UV (MeOH) $\lambda_{\max }(\log \varepsilon) 210$ (4.25), 263 (3.76), 310 (3.92) nm; IR (KBr) $v_{\max } 3,422,3,085,2,914,2,867,1,725,1,652,1,598,1,540,1,457,1,379,1,226$, $1,138,1,076,886,748 \mathrm{~cm}^{-1}$; ESIMS $\mathrm{m} / z$ (positive ion mode) $427[\mathrm{M}+\mathrm{Na}]^{+}$; HRESIMS (positive ion mode) $m / z 427.1001[\mathrm{M}+\mathrm{Na}]^{+}$(calcd. $\mathrm{C}_{20} \mathrm{H}_{20} \mathrm{NaO}_{9}$ for 427.1005 ).

\subsection{Anti-TMV Assays}

The anti-TMV activities were tested using the half-leaf method [15]. Ningnanmycin (2\% water solution), a commercial product for plant disease in China, was used as a positive control.

\section{Conclusions}

Three new xanthones 1-3 and five known analogues 4-8 were isolated from the acetone extract of the leaves of Garcinia paucinervis. All the compounds were evaluated for anti-tobacco mosaic virus (anti-TMV) activities. Compounds 1-3 showed potent anti-TMV activities, with inhibition rate, above $20 \%$. Compound 1 had a lower $\mathrm{IC}_{50}$ value of $21.4 \mu \mathrm{M}$.

\section{Supplementary Materials}

Supplementary materials (NMR spectra of 1-3) can be accessed at: http://www.mdpi.com/ 1420-3049/18/8/9663/s 1 .

\section{Acknowledgments}

This research was supported by the National Natural Science Foundation of China (No. 21002085), The Funds of Yunnan Tobacco Monopoly Bureau (2011YN01), the Excellent Scientific and Technological Team of Yunnan High School (2010CI08), the Yunnan University of Nationalities Green Chemistry and Functional Materials Research for Provincial Innovation Team (2011HC008).

\section{Conflict of Interest}

The authors declare no conflict of interest.

\section{References}

1. Sakagami, Y.; Iinuma, M.; Piyasena, K.G.; Dharmaratne, H.R. Antibacterial activity of $\alpha$-mangostin against vancomycin resistant Enterococci (VRE) and synergism with antibiotics. Phytomedicine 2005, 12, 203-208.

2. Gopalakrishnan, G.; Banumathi, B.; Suresh, G. Evaluation of the antifungal activity of natural xanthones from Garcinia mangostana and their synthetic derivatives. J. Nat. Prod. 1997, 60, 519-524. 
3. Nakatani, K.; Yamakuchi, T.; Kondo, N.; Arakawa, T.; Oosawa, K.; Shimura, S.; Inoue, H.; Ohizumi, Y. $\gamma$-Mangostin inhibits inhibitor-kB kinase activity and decreases lipopolysaccharideinduced cyclooxygenase-2 gene expression in C6 rat glioma cells. Mol. Pharmacol. 2004, 66, 667-674.

4. Jung, H.A.; Su, B.N.; Keller, W.J.; Kinghorn, A.D. Antioxidant xanthones from the pericarp of Garcinia mangostana (Mangosteen). J. Agric. Food Chem. 2006, 54, 2077-2082.

5. Gao, X.M.; Yu, T.; Lai, F.; Zhou, Y.; Liu, X.; Qiao, C.F.; Song, J.Z.; Chen, S.L.; Luo, K.Q.; $\mathrm{Xu}$, H.X. Identification and evaluation of apoptotic compounds from Garcinia paucinervis. Bioorg. Med. Chem. 2010, 18, 4957-4964.

6. Gao, X.M.; Yu, T.; Lai, F.; Qiao, C.F.; Zhou, Y.; Liu, X.; Song, J.Z.; Luo, K.Q.; Xu, H.X. Novel polyisoprenylated benzophenone derivatives from Garcinia paucinervis. Tetrahedron Lett. 2010, 51, 2442-2446.

7. Han, Q.B.; Wang, Y.L.; Yang, L.; Tso, T.F.; Qiao, C.F.; Song, J.Z.; Xu, L.J.; Chen, S.L.; Yang, D.J.; Xu, H.X. Cytotoxic polyprenylated xanthones from the resin of Garcinia hanburyi. Chem. Pharm. Bull. 2006, 54, 265-267.

8. Li, X.W.; Li, J.; Stevens, P.F. Flora of China; Science Press: Beijing, China, 2007; Volume 13.

9. Rukachaisirikul, V.; Kamkaew, M.; Sukavisit, D.; Phongpaichit, S.; Sawangchote, P.; Taylor, W.C. Antibacterial xanthones from the leaves of Garcinia nigrolineata. J. Nat. Prod. 2003, 66, 1531-1535.

10. Hoison, O.; Cuong, D.D.; Gramain, A.; Anthony, C.; Angele, H.; Nguyen, V.; Sevenet, T. Further rearranged prenylxanthones and benzophenones from Garcinia bracteata. Tetrahedron 2005, 61, 8529-8535.

11. Bayma, J.C.; Arruda, M.S.P.; Neto, M.S. A prenylated xanthone from the bark of Symphonia globulifera. Phytochemistry 1998, 49, 1159-1160.

12. Hano, Y.; Matsumoto, Y.; Sun, J.; Nomura, T. Constituents of the Moraceae plants. Part 1. Components of root bark of Cudrania tricuspidata. Part 4. Structures of three new isoprenylated xanthones, cudraxanthones E, F, and G. Planta Med. 1990, 56, 399-402.

13. Nguyen, L.D.; Vo, H.T.; Pham, H.D.; Connolly, J.D.; Harrison, L.J. Xanthones from the bark of Garcinia merguensis. Phytochemistry 2003, 63, 467-470.

14. Yan, X.H.; Chen, J.; Di, Y.T.; Fang, X.; Dong, J.H.; Sang, P.; Wang, Y.H.; He, H.P.; Zhang, Z.K.; Hao, X.J. Anti-Tobacco Mosaic Virus (TMV) quassinoids from Brucea javanica (L.) Merr. J. Agric. Food Chem. 2010, 58, 1572-1577.

15. Song, B.A.; Zhang, H.P.; Wang, H.; Yang, S.; Jin, L.H.; Hu, D.Y.; Pang, L.L.; Xue, W. Synthesis and antiviral activity of novel chiral cyanoacrylate derivatives. J. Agric. Food Chem. 2005, 53, 7886-7891.

Sample Availability: Samples of the compounds 1-3 are available from the authors.

(C) 2013 by the authors; licensee MDPI, Basel, Switzerland. This article is an open access article distributed under the terms and conditions of the Creative Commons Attribution license (http://creativecommons.org/licenses/by/3.0/). 